\title{
Otolith chemistry reflects frontal systems in the Antarctic Circumpolar Current
}

\author{
J. R. Ashford ${ }^{1, *}$, A. I. Arkhipkin ${ }^{2}$, C. M. Jones ${ }^{1}$ \\ ${ }^{1}$ Center for Quantitative Fisheries Ecology, Old Dominion University, 800 West $46^{\text {th }}$ Street Norfolk, Virginia 23529, USA \\ ${ }^{2}$ Fisheries Department, Falkland Islands Government, PO Box 598, Stanley FIQQ 1ZZ, Falkland Islands
}

\begin{abstract}
Pronounced environmental trends across fronts suggest that the otolith chemistry of oceanic fish can resolve zones on either side, promoting application to population questions at similar spatial scales. Trace and minor elements laid down immediately prior to capture-along the edges of otoliths from Patagonian toothfish Dissostichus eleginoides-discriminated frontal zones in the Antarctic Circumpolar Current in the Southwestern Atlantic Ocean. Mean values differentiated sampling areas by up to 2.6 standard deviations, suggesting: (1) otolith $\mathrm{Mg} / \mathrm{Ca}$ enrichment related to fish activity around the Burdwood Bank; (2) Mn/Ca enrichment associated with South America; (3) $\mathrm{Sr} / \mathrm{Ca}$ linked to the presence of Circumpolar Deep Water; and (4) Ba/Ca to nutrient production and mixing. In the Polar Frontal Zone, meanders or eddies may account for affinities with neighbouring sampling areas, bringing water from the Subantarctic and Antarctic Zones onto the North Scotia Ridge. Moreover, fish age showed a significant relationship with depth and improved cross-validation by $14 \%$, giving $85 \%$ classification rates to South American and Antarctic regions, and 57 to $83 \%$ to areas along the Patagonian Shelf. These results indicate that otolith chemistry reflects hydrography, detecting oceanic gradients across the slope of continental shelves and between zones separated by strong trends like fronts.
\end{abstract}

KEY WORDS: Otoliths · Spatial ecology · Fishery $\cdot$ Laser-ICPMS $\cdot$ Patagonian toothfish $\cdot$ Southern Ocean

Resale or republication not permitted without written consent of the publisher

\section{INTRODUCTION}

\section{Otolith chemistry and the environment}

Successful discrimination of spatial provenance using otolith chemistry has promoted innovative research on population structure and movement in fish (e.g. Campana 1999, Thresher 1999). In oceanic environments, the biogeochemical array recorded in otoliths originates from wind-driven, riverine, and geothermal sources. But physical processes frequently control dispersal of these inputs, and therefore how the biogeochemistry is distributed spatially (e.g. Donat \& Bruland 1995). Pronounced changes across fronts should make it easier to discriminate fish provenance over small spatial scales. On the other hand, zones between fronts, which show less heterogeneity, might make discrimination difficult, even when fish are separated by large distances.

Physical processes frequently structure populations as well. Oceanic fronts are often cited as barriers that prevent population exchange (e.g. Loeb et al. 1993), associated with fast-moving currents, which mitigate cross-frontal movement and lead to advective loss by transporting vulnerable life stages away from suitable habitat. Under these conditions, the ambient biogeochemistry structured by fronts (e.g. Pollard et al. 2002) varies at a spatial scale that matches the population processes, rendering otolith chemistry powerfully suited to resolve population structure. Yet fronts are often permeable, and fish carry chemistry in their otoliths corresponding to earlier exposure (e.g. Campana 1999), which researchers can use to unravel complex movement between zones. In contrast, when pop- 
ulation structuring occurs where differences in biogeochemistry are small, the mismatch can render the technique ineffective. The research questions that otolith chemistry can address, therefore, depend on whether the scale at which it varies matches the scale at which populations are structured.

\section{Environmental structuring by the Antarctic Circumpolar Current (ACC)}

The ACC connects the southern hemisphere continents and islands and banks around the Antarctic. Within it, the Subantarctic Front (SAF), Polar Front $(\mathrm{PF})$, and Southern ACC Front (SACCF) are identifiable around the continent (Orsi et al. 1995), penetrate the entire water column (e.g. Nowlin \& Clifford 1982) and appear stable where they flow over large bathymetric features (Hofmann 1985). Frontal current jets account for most ACC transport. Between them are quiescent zones of slower moving water. The Subantarctic Zone is bounded on its equatorial side by the Subtropical Front (STF) and poleward by the SAF. Between the SAF and the PF lies the Polar Frontal Zone; south of the PF is the Antarctic Zone (Pollard et al. 2002).

The contribution of temperature and salinity to vertical stratification distinguishes the 3 zones (Pollard et al. 2002). In the Subantarctic Zone, temperature dominates over salinity, so that a subsurface salinity minimum associated with Antarctic Intermediate Water (AAIW) is stable because of relatively warm surface waters. In the Polar Frontal Zone, temperature and salinity are equally important, whereas in the Antarctic Zone, salinity is more important so that a temperature maximum associated with Circumpolar Deep
Water (CDW) is stable. Nutrients are raised from depth by vertical mixing and by advection and mixing along density surfaces that slope upward towards the pole, bringing nutrient-rich CDW close to the surface. However, the slope of these isopycnal surfaces is often concentrated within fronts and, even where the density gradients are less pronounced, temperature and salinity vary markedly with their changing role in stratification.

In the Southwestern Atlantic Ocean (Fig. 1), the fronts flow through deep water troughs in the North Scotia Ridge (e.g. Orsi et al. 1995, Arhan et al. 2002). The SAF passes east of the Burdwood Bank and along the slope of the Patagonian Shelf. East of the Falkland Islands, it reaches the slope floor at approximately the $1800 \mathrm{~m}$ isobath (Arhan et al. 2002), delineating the poleward limit of the Subantarctic Zone. The PF passes west of Shag Rocks, separating the Polar Frontal Zone from the Antarctic Zone. The Southwestern Atlantic is where AAIW is principally formed; and North Atlantic Deep Water (NADW), transported from its northern source areas, mixes with Antarctic water to form CDW (e.g. Meredith et al. 1999). As a result, the area is characterized by water masses close to their origin, where the contrast in their properties is most well-defined.

\section{Do otolith chemistry and population structure vary at matching scales?}

Patagonian toothfish Dissostichus eleginoides Smitt, 1898 are captured by benthic longline from deep water along the continental slopes of southern South America and islands and seamounts in the Southern Ocean. They are managed as spatially discrete stocks within national Exclusive Economic Zones and fishing areas

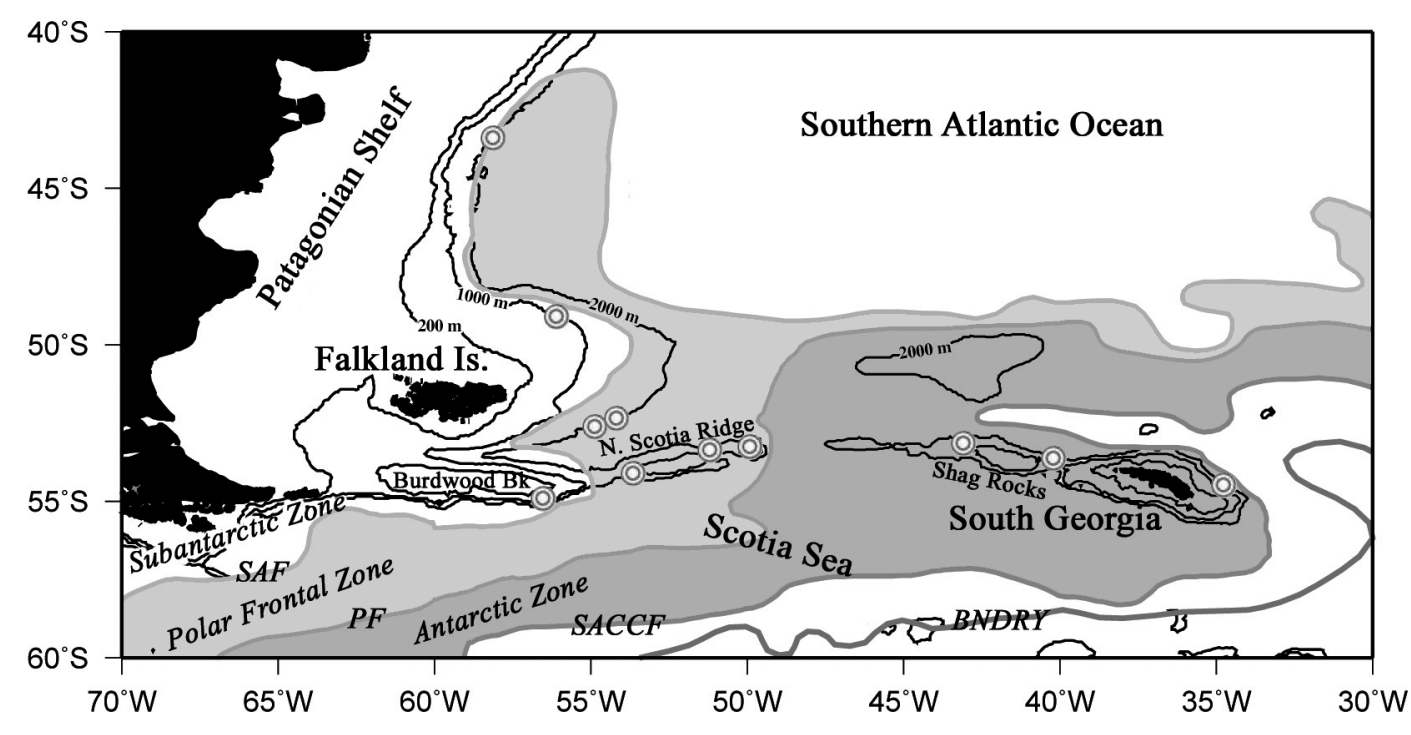

Fig. 1. Sampling areas in the Southwestern Atlantic Ocean. SAF: Subantarctic Front; PF: Polar Front; SACCF: Southern Antarctic Circumpolar Current (ACC) Front; BNDRY: southern boundary of the ACC. Front positions taken from Orsi et al. (1995) 
broadly corresponding to island groups under the Convention for the Conservation of Antarctic Marine Living Resources (CCAMLR). As bentho-pelagic predators, they live to 50+ yr (e.g. Ashford 2001, Horn 2002), grow to a maximum total length (TL) of $>2 \mathrm{~m}$, and show a linear increase in TL with depth (Agnew et al. 1999).

Available evidence indicates young stages are pelagic (North 2002), and neutrally buoyant adults (Eastman 1993) are capable of large-scale movement (e.g. Moller et al. 2003). Genetic data indicate considerable population heterogeneity (e.g. Smith \& McVeagh 2000, Appleyard et al. 2002) and a substantial barrier to gene flow between the North Scotia Ridge and South Georgia (Shaw et al. 2004, Rogers et al. 2006). These results corroborated length-at-age data that imply that the ACC structures populations by mitigating cross-frontal movement and promoting advection of vulnerable life stages downstream (Ashford 2001, Ashford et al. 2003). A population boundary in the vicinity of the PF is also consistent with separate spawning on Burdwood Bank during May and August between 1992 and 2002 (Laptikovsky et al. 2006) and during winter at South Georgia (Agnew et al. 1999).

The chemistry laid down during early life in the nuclei of otoliths from the same fish as Shaw et al. (2004) successfully resolved this population boundary (Ashford et al. 2006). It also suggested population heterogeneity off South America, with considerable movement of adults across the SAF. But to study adult movement further, we need to establish whether variation in otolith chemistry can underpin tests of hypotheses. Trace and minor elements laid down along the otolith edges of adult toothfish in the period directly prior to capture showed strong contrasts between the Patagonian Shelf and South Georgia (Ashford et al. 2005). Enriched otolith $\mathrm{Mn} \mathrm{Ca}^{-1}$ off South America was most likely linked to authigenic activity at the oceansediment interface, or resuspension from anoxic sedi- ments (e.g. Bucciarelli et al. 2001). Ambient temperature most likely drove differences in otolith $\mathrm{Sr} \mathrm{Ca}{ }^{-1}$ through its effect on growth rates (Campana 1999); whereas fish exposed to Ba-rich water incorporate more $\mathrm{Ba} \mathrm{Ca}^{-1}$ in their otoliths (Campana 1999), and $\mathrm{Ba}$, following a nutrient-type distribution, accumulates in the ACC in association with new production fueled by nitrate (e.g. Dehairs et al. 1992). Therefore, we examined otolith trace element chemistry across the ACC, at scales down to 200 nautical miles along the Patagonian Shelf and North Scotia Ridge, to see whether oceanic fronts can produce contrasts large enough to underpin tests of population hypotheses.

\section{MATERIALS AND METHODS}

Otolith analyses. Trace and minor element concentrations were measured in the outer edges of Patagonian toothfish otoliths collected by Ashford et al. (2006). The otoliths were sampled by scientific observers placed on commercial benthic longliners over 4 mo during the austral winter-spring of 2001, so that otoliths contained a complete opaque zone (Horn 2002) corresponding to that year. Nine areas were sampled along the continental slope (Fig. 1, Table 1). Four were in the Subantarctic Zone: in international waters north of the Falkland Islands (taken at a depth of $1600 \mathrm{~m}$ ); in the Falkland Islands Conservation Zone (FCZ) northeast (at $980 \mathrm{~m}$ ) and east (at 1650 to $1700 \mathrm{~m}$ ) of the Falkland Islands; and on the southern side of the Burdwood Bank (at 1200 m). In the Polar Frontal Zone, samples were taken southwest (at $1050 \mathrm{~m}$ ) and northeast of the North Scotia Ridge (at 950 to $1200 \mathrm{~m}$ ). Three samples were taken in the Antarctic Zone: of these, 2 taken from west and east of Shag Rocks were pooled because they contained small numbers of fish (1100 to $1250 \mathrm{~m})$; the third was collected from the east side of South Georgia (1400 m). Observers sampled toothfish from

Table 1. Dissostichus eleginoides. Sample size $(\mathrm{n})$, age ( $\mathrm{yr}_{;}$mean $\left.\pm \mathrm{SD}\right)$, total length $\left(\mathrm{TL}_{i}\right.$ mean $\left.\pm \mathrm{SD}\right)$, weight $(g ;$ mean $\pm \mathrm{SD})$, and number of each sex. FCZ: Falkland Islands Conservation Zone; nd: no data

\begin{tabular}{|lrrrrr|}
\hline Sampling area & $\mathrm{n}$ & Age (yr) & TL (cm) & Weight (g) & Males/Females \\
\hline Subantarctic Zone & & & & & \\
International & 28 & $13.1(4.8)$ & $94.9(10.4)$ & $9410(3380)$ & $11 / 17$ \\
North FCZ & 42 & $9.2(3.4)$ & $76.9(10.7)$ & $5881(1783)$ & nd \\
East FCZ & 43 & $16.5(4.5)$ & $109.4(14.9)$ & $15035(6315)$ & $14 / 29$ \\
South FCZ & 45 & $10.5(4.1)$ & $83.3(12.6)$ & $6422(3051)$ & $25 / 20$ \\
Polar Frontal Zone & & & & & \\
West & 45 & $11.5(4.6)$ & $91.4(21.1)$ & $9989(11014)$ & $28 / 17$ \\
East & 34 & $12.5(3.7)$ & $96.3(12.5)$ & $9941(4492)$ & $18 / 16$ \\
Antarctic Zone & & & & \\
Shag Rocks & 45 & $11.0(3.6)$ & $84.7(09.6)$ & $6356(2273)$ & $15 / 30$ \\
South Georgia & 42 & $13.5(5.2)$ & $95.1(17.2)$ & $9917(5755)$ & $19 / 23$ \\
\hline
\end{tabular}


the catch and recorded TL, weight, sex, and maturity stages, except in the north FCZ where sex was not recorded. Otoliths were collected using plastic forceps to avoid metal contamination, stored dry in oil-paper envelopes, and transported to Old Dominion University in Norfolk, Virginia, USA.

To account for ontogenetic effects on otolith chemistry, we estimated age for each fish, randomly selecting 1 sagittal otolith from each pair and baking and grinding to give transverse sections through the nuclei. Full preparation details are given in Ashford et al. (2006). Otoliths were read in random order using the ageing criteria agreed at the 2001 CCAMLR Workshop on Estimating Age in Patagonian Toothfish, which have been tested in validation studies using marginal increment analysis (Horn 2002) and modal length analysis (Ashford et al. 2002).

The remaining sagittal otolith from each fish was used for measuring concentrations of trace and minor elements. To remove any surface contamination, otoliths were rinsed in Milli-Q water, placed in $20 \%$ UltraPure hydrogen peroxide for $5 \mathrm{~min}$, and rinsed again. They were then ground to produce thick transverse sections mounted on slides using crystal bond, which had been previously tested to ensure it was not a source of contamination. In a Class 100 clean room, the sections were rinsed in Milli-Q water under a laminar flow hood, and lapped manually using clean plastic clamps and Mark V Laboratory polishing film. Each otolith was lapped successively on 3 pieces of clean $3 \mathrm{M}$ film, finished on $0.3 \mathrm{M}$ film, rinsed, and the surface soaked with $20 \%$ Ultra-Pure hydrogen peroxide for 5 min before rinsing again. After drying, sections from each treatment were randomly selected, removed from the slide, and mounted in random order on clean petrographic slides under a laminar-flow hood using silicon glue, also previously tested to ensure it was not a source of contamination. The mounted sections were rinsed, sonicated for $5 \mathrm{~min}$, and rinsed again, all in Milli-Q water, and left to dry.

To measure minor and trace element concentrations along the otolith edges, we used the Finnegan Mat Element 2 double-focusing sector-field Inductively Coupled Plasma Mass Spectrometer (ICPMS) located at the Laboratory for Isotope and Trace Element Research (LITER) at Old Dominion University. Samples were introduced into ICP in automated sequence using a combination of laser ablation by a New Wave Research EO LUV 266 laser ablation system and solution nebulization using a PFA microflow nebulizer

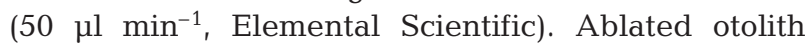
material from the sample cell was mixed in the spray chamber with aerosol of $1 \% \mathrm{HNO}_{3}$ introduced by the nebulizer, and the mixture was then carried to the ICP torch. Laboratory calibration standards consisted of known-concentration multi-element solutions synthesized from stock single element standards, and were similarly introduced to the spray chamber by the nebulizer as an aerosol before being carried to the ICP torch. Blanks of $1 \% \mathrm{HNO}_{3}$ aerosol were also introduced to the chamber by the nebulizer. For quality control, we used dissolved otolith reference material obtained from the National Research Council of Canada, for which replicate analyses showed relative standard deviations of less than $3 \%$ for certified elements, including $\mathrm{Mg}, \mathrm{Ca}, \mathrm{Mn}, \mathrm{Sr}$, and $\mathrm{Ba}$. To control for operational variability in the laser-ICPMS, a randomized block design was used with each petrographic slide as the blocking factor, considered randomly drawn, with each sampling area considered a fixed treatment. Blank and standard readings of count rate (counts $\mathrm{s}^{-1}$ ) were obtained before and after random presentation of the otolith sections in each block. Readings of reference material were obtained before sample presentation. To calculate element:Ca (Me/Ca) ratios, background counts were subtracted from otolith counts by interpolating between readings taken before and after each block of otoliths, and the corrected otolith counts were converted to $\mathrm{Me} / \mathrm{Ca}$ concentrations using the standards. Otoliths were analysed for ${ }^{42} \mathrm{Ca}$, ${ }^{25} \mathrm{Mg},{ }^{55} \mathrm{Mn},{ }^{88} \mathrm{Sr}$, and ${ }^{137} \mathrm{Ba}$ and reported as ratios to ${ }^{42} \mathrm{Ca}$. A line raster type was placed along the proximodorsal edge with a laser beam of diameter $20 \mu \mathrm{m}$, frequency at $10 \mathrm{~Hz}$, and power at $60 \%$, travelling ca. $900 \mu \mathrm{m}$ along the edge at $6 \mu \mathrm{m} \mathrm{s}^{-1}$ and giving a predicted mean crater width of $17 \mu \mathrm{m}$, corresponding to the 2001 annulus, and crater depth of approximately $100 \mu \mathrm{m}$.

Statistical methods. To see if otolith chemistry could detect frontal zones, data were examined for differences using hierarchical ANOVA, with zone and sampling area within zone considered fixed factors at different spatial scales. Outliers were identified by plotting robust squared Mahalanobis distances of the multivariate residuals $\left(D^{2}{ }_{i}\right)$ against the corresponding quantiles (Q-Q plot) of the chi-square distribution (Khattree \& Naik 1999). Univariate variances showed an increase with mean values (Fig. 2), and we transformed the data to an appropriate scale to stabilize the variances (Kuehl 1994). Power transformations were estimated empirically using:

$$
\log \left(\sigma_{i}\right)=\log (\alpha)+\beta\left(\log \mu_{i}\right)
$$

where $\sigma_{i}=$ the standard deviation of the $i$ th treatment, $\mu_{\mathrm{i}}=$ the mean of the $i$ th treatment, and $\alpha=$ the constant of proportionality. By substituting estimates of the mean and standard deviations from our treatments, $\beta$ was estimated using simple linear regression, taking $\hat{p}=1-\hat{\beta}$, where $y^{\hat{p}}$ is the variance-stabilizing transformation (Kuehl 1994). Following minor adjustment 

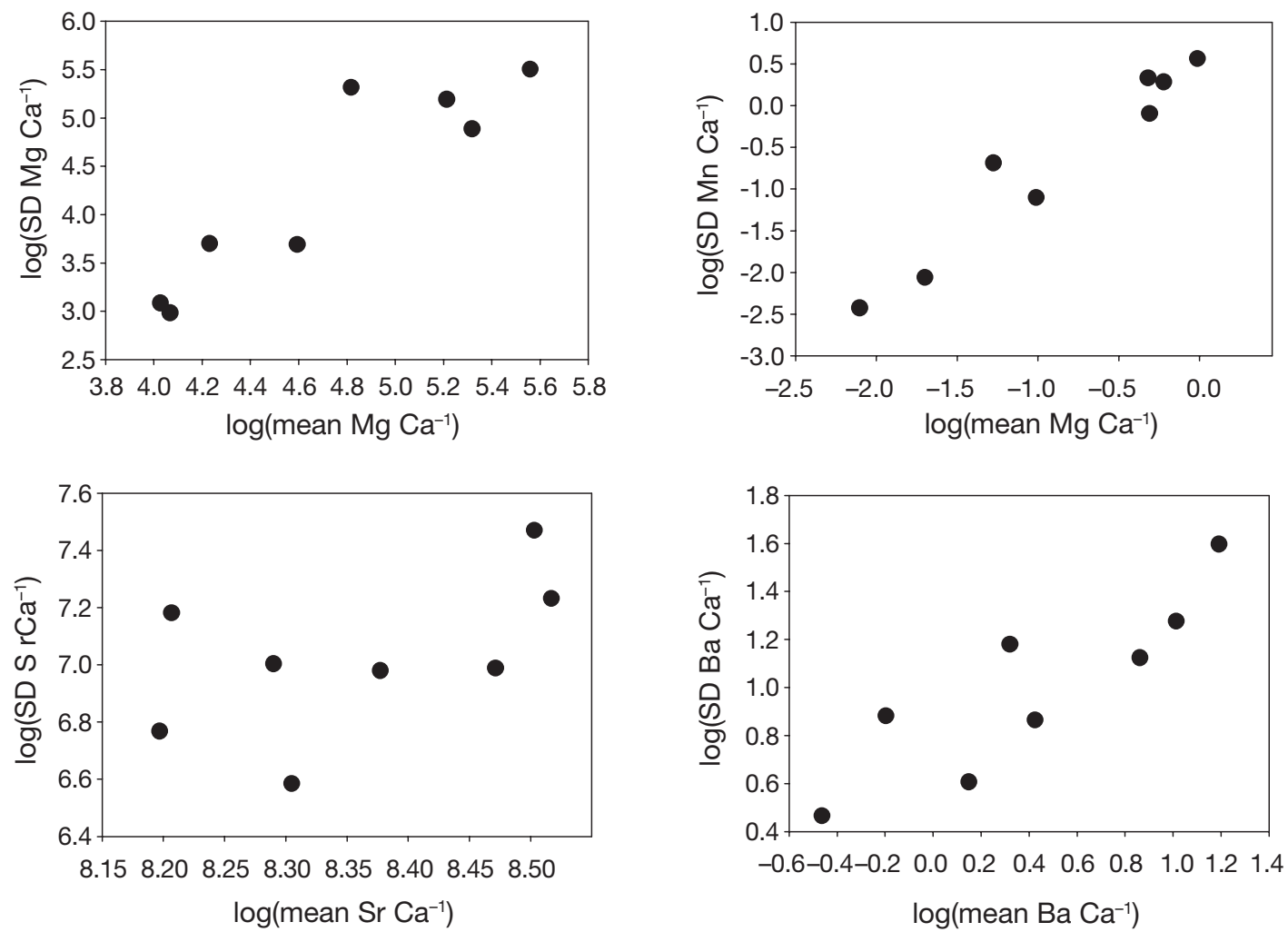

Fig. 2. Dissostichus eleginoides. Relationship between standard deviation and mean concentrations $\left(\mu \mathrm{mol} \mathrm{mol}{ }^{-1}\right) \mathrm{of} \mathrm{Mg} \mathrm{Ca}^{-1}$, $\mathrm{Mn} \mathrm{Ca}^{-1}, \mathrm{Sr} \mathrm{Ca}^{-1}$ and $\mathrm{Ba} \mathrm{Ca}{ }^{-1}$ along otolith edges

around $y^{\hat{p}}$, the data transformations selected were $y^{-0.8}$ for $\mathrm{Mg} \mathrm{Ca}^{-1}, y^{-0.8}$ for $\mathrm{Mn} \mathrm{Ca}^{-1}, y^{-0.25}$ for $\mathrm{Sr} \mathrm{Ca}^{-1}, y^{-0.25}$ for $\mathrm{Ba} \mathrm{Ca}^{-1}$.

Using the univariate data, the effects due to age and sex were tested for each trace and minor element ratio by ANCOVA with age as a covariate and sex as a blocking factor. Interaction effects were insignificant, indicating the relationship between the elemental ratio and both age and sex were the same between treatments. Since $\mathrm{Mg} \mathrm{Ca}^{-1}$ and $\mathrm{Mn} \mathrm{Ca}^{-1}$ showed no significant effects due to age or sex, the covariate and block were dropped. However, sampling areas in the Polar Frontal Zone showed unexpected affinities with neighbouring zones in the hierarchical model. Consequently, we analyzed the data using a 1-way ANOVA with sampling area as a single fixed factor and examined for differences between all sampling areas using Student-Newman-Keuls (SNK) tests.

For $\mathrm{Sr} \mathrm{Ca}{ }^{-1}$ and $\mathrm{Ba} \mathrm{Ca}^{-1}$, age and sex showed significant effects. As a result, the full hierarchical model, with covariate and blocking factor, was run for $\mathrm{Sr} \mathrm{Ca}^{-1}$ and $\mathrm{Ba} \mathrm{Ca}{ }^{-1}$ without the north FCZ samples for which sex data were not available. The results were then compared with the model without blocks for all 8 treatments. Again, differences between sampling areas in the Polar Frontal Zone clearly reflected similarities with neighbouring zones, so data were re-analyzed using a 1-way ANCOVA with sampling area as a single fixed factor and age as a covariate. To compare between treatments, the probability levels of tests between the adjusted means were examined for all possible combinations of the hypothesis $H_{0}: \bar{y}_{i}=\bar{y}_{j}$. Residuals fulfilled all parametric assumptions for both $\mathrm{Sr} \mathrm{Ca}^{-1}$ and $\mathrm{Ba} \mathrm{Ca}{ }^{-1}$.

To examine whether the univariate contrasts between sampling areas were strong enough to support accurate classification of provenance, we evaluated the data graphically and using multivariate discriminant analysis (MDA). Age was incorporated as a fifth variable with the 4 element ratios because it showed evidence of a spatial relationship with depth (Fig. 3). To stabilize variances between treatments, the power transformation for age was estimated as $y^{0.1}$; transformed data conformed to univariate normality. Based on Mardia's multivariate skewness and kurtosis measures, and Q-Q plots of squared Mahalanobis distances $\left(d^{2}{ }_{i}\right)$, the transformed data for age and trace and minor elements conformed to multivariate normality. However, they did not fulfill the assumption of equal variance-covariance matrices, so we could not use canoni- 


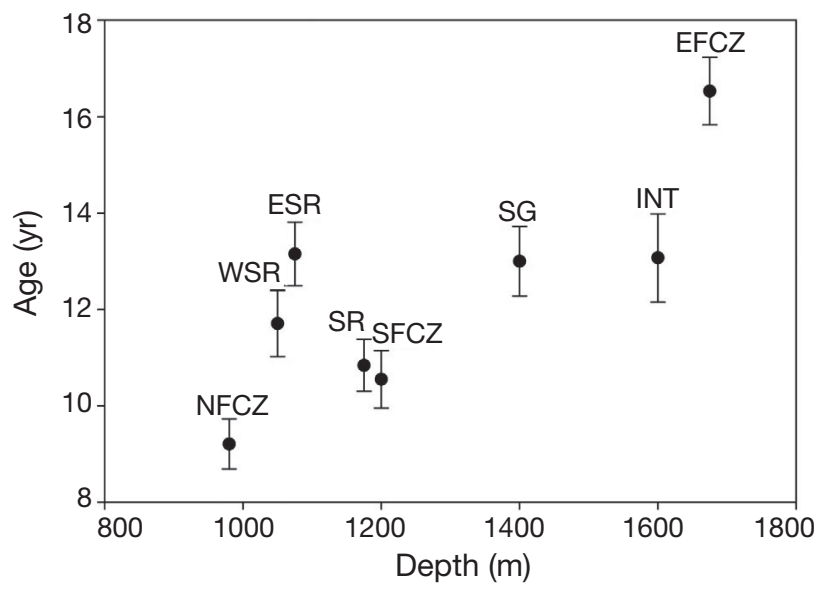

Fig. 3. Dissostichus eleginoides. Depth (m) and mean age (yr; mean \pm SE) interpreted from otolith growth increments. Sampling areas: international waters (INT); north Falkland Islands Conservation Zone (NFCZ); east FCZ (EFCZ); south FCZ (SFCZ); western Scotia Ridge (WSR); eastern Scotia Ridge (ESR); Shag Rocks (SR); South Georgia (SG)

cal discriminant analysis. Instead, transformed data were evaluated graphically using non-metric multidimensional scaling (nMDS) (Kruskal \& Wish 1978). Because the variables had different absolute magnitudes and ranges, they were standardized to the same scale (mean $\pm \mathrm{SD} 0 \pm 1$ ) prior to computing the distance matrix. A dissimilarity matrix was constructed based on Euclidean distances. From this, a 2-dimensional projection of distance between individual fish was created using a convergence criterion of stress < 0.01 , where stress is a measure of the fit of the data to the configuration. MDA requires prior evidence of differences between treatments (Khattree \& Naik 2000) considered evident from the univariate analyses. Incorporating age as a response variable accounted for the relationships between age and element ratios in the variance-covariance matrices. As a result, we applied MDA, using individual variance-covariance matrices in a quadratic MDA because variance-covariance matrices were not equal. Error rates were estimated by cross-validation, with proportional prior probabilities.

\section{RESULTS}

Fish ages were similar in most sampling areas: there were no significant differences between international waters, the western and eastern North Scotia Ridge, Shag Rocks and South Georgia. However, fish from the eastern FCZ were significantly older than from all other areas (Fig. 3), north FCZ and south FCZ fish were significantly younger than some other areas (ANOVA: $\mathrm{p}<0.05)$. The relationship between mean transformed age and depth was age $=[1.2+(0.00007 \times$ depth $)]\left(\mathrm{r}^{2}=\right.$ $0.58, \mathrm{p}<0.027)$. Otolith chemistry showed pronounced differences between the Subantarctic Zone and Antarctic Zone (Fig. 4). Samples taken off the Patagonian Shelf and Burdwood Bank had higher mean concentrations of $\mathrm{Mn} \mathrm{Ca}^{-1}$, between $0.36 \pm 0.05 \mu \mathrm{mol} \mathrm{mol}^{-1}$ (mean $\pm \mathrm{SE}$ ) at north FCZ and $0.99 \pm 0.26 \mu \mathrm{mol} \mathrm{mol}{ }^{-1}$ at south FCZ, than those at South Georgia (0.28 \pm $\left.0.08 \mu \mathrm{mol} \mathrm{mol}{ }^{-1}\right)$ and Shag Rocks $(0.18 \pm 0.02 \mu \mathrm{mol}$ $\mathrm{mol}^{-1}$ ). On the other hand, they had lower mean concentrations of $\mathrm{Sr} \mathrm{Ca}^{-1}$ : between $3630.2 \pm 134.2 \mu \mathrm{mol}$ $\mathrm{mol}^{-1}$ at north FCZ and $4043.9 \pm 136.7 \mu \mathrm{mol} \mathrm{mol}{ }^{-1}$ in international waters, compared to $4347.2 \pm 160.2 \mu \mathrm{mol}$ $\mathrm{mol}^{-1}$ at Shag Rocks and $4930.6 \pm 270.6 \mu \mathrm{mol} \mathrm{mol}{ }^{-1}$ at South Georgia. Similarly, $\mathrm{Ba} \mathrm{Ca}{ }^{-1}$ concentrations varied between $1.59 \pm 0.10 \mu \mathrm{mol} \mathrm{mol}{ }^{-1}$ at north FCZ

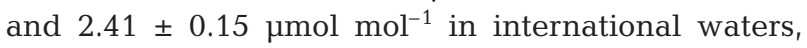
compared to $3.07 \pm 0.35 \mu \mathrm{mol} \mathrm{mol}{ }^{-1}$ at Shag Rocks and $3.58 \pm 0.42 \mu \mathrm{mol} \mathrm{mol}{ }^{-1}$ at South Georgia.

A notable exception was at east FCZ, where mean $\mathrm{Sr}$ $\mathrm{Ca}^{-1}$ was $4776.4 \pm 165.3 \mu \mathrm{mol} \mathrm{mol}{ }^{-1}$ and mean $\mathrm{Ba} \mathrm{Ca}^{-1}$ was $3.25 \pm 0.21 \mu \mathrm{mol} \mathrm{mol}{ }^{-1}$, similar to Shag Rocks and South Georgia. In the Polar Frontal Zone, fish from the western North Scotia Ridge showed a similar chemistry to the Patagonian Shelf, with mean $\mathrm{Mn} \mathrm{Ca}^{-1}$ of $0.73 \pm 0.21 \mu \mathrm{mol} \mathrm{mol}^{-1}, \mathrm{Sr} \mathrm{Ca}^{-1}$ of $3984.3 \pm 164.0 \mu \mathrm{mol}$ $\mathrm{mol}^{-1}$, and $\mathrm{Ba} \mathrm{Ca}^{-1}$ of $2.37 \pm 0.23 \mu \mathrm{mol} \mathrm{mol}^{-1}$. Fish from the eastern North Scotia Ridge were more similar to Shag Rocks and South Georgia, with mean $\mathrm{Mn} \mathrm{Ca}^{-1}$ of $0.12 \pm 0.01 \mu \mathrm{mol} \mathrm{mol}{ }^{-1}, \mathrm{Sr} \mathrm{Ca}^{-1}$ of $4999.8 \pm 237.1 \mu \mathrm{mol}$ $\mathrm{mol}^{-1}$, and $\mathrm{Ba} \mathrm{Ca}{ }^{-1}$ of $4.94 \pm 0.56 \mu \mathrm{mol} \mathrm{mol}{ }^{-1}$. Mean concentrations of $\mathrm{Mg} \mathrm{Ca}^{-1}$ were high closest to where the SAF crosses the Scotia Ridge, between $183.7 \pm$ $26.8 \mu \mathrm{mol} \mathrm{mol} \mathrm{m}^{-1}$ off the western Scotia Ridge and $259.7 \pm 37.4 \mu \mathrm{mol} \mathrm{mol}^{-1}$ at east FCZ.

For $\mathrm{Mg} \mathrm{Ca}^{-1}$, data showed evidence of minor departure from assumptions: although variances were homogeneous between sampling areas $\left(F_{\max }, \alpha=0.01\right)$, samples from the eastern and southern FCZ and western and eastern North Scotia Ridge all showed mild skewness and kurtosis. However, ANOVA is robust to departure from normality and examination of the residuals showed the departure was not extreme. The hierarchical ANOVA showed significant differences between and within zones $(\mathrm{p}<0.5)$; SNK tests showed the means for all 3 zones separated significantly. However, the western Scotia Ridge showed affinity with nearby sampling areas in the Subantarctic Zone and the eastern Scotia Ridge with sampling areas in the Antarctic Zone, so we used 1-way ANOVA to examine differences between individual sampling areas (Table 2a). Consistent with the evidence from the untransformed means (Fig. 4), sampling areas were significantly different (ANOVA: $p<0.05$ ). SNK tests 

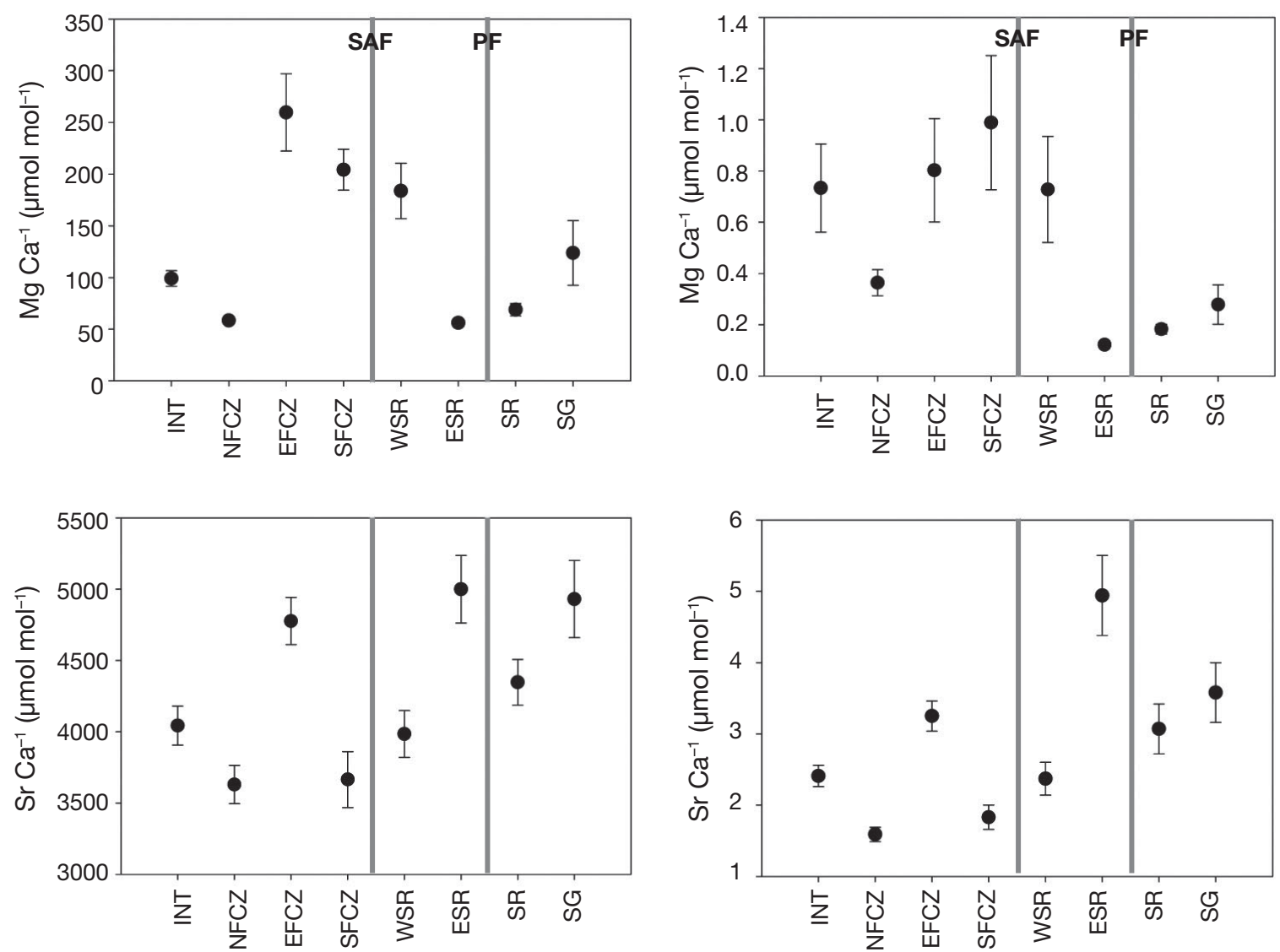

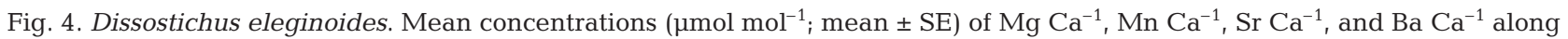
otolith edges. SAF: Subantarctic Front; PF: Polar Front. Sampling areas are as defined in Fig. 3

separated the eastern FCZ, southern FCZ, and western Scotia Ridge from all other sampling areas except international waters, which showed similarity to the western Scotia Ridge. Mean $\mathrm{Mg} \mathrm{Ca}^{-1}$ values in fish in international waters and off South Georgia were also significantly different from those in the northern FCZ, off the eastern Scotia Ridge, and Shag Rocks.

Table 2. Dissostichus eleginoides. Mean square estimates for chemistry of otolith edges from: (a) 1-way ANOVA for $\mathrm{Mg} \mathrm{Ca}^{-1}$ and $\mathrm{Mn} \mathrm{Ca}{ }^{-1}$; (b) 1-way ANCOVA for $\mathrm{Sr} \mathrm{Ca}^{-1}$; for $\mathrm{Ba} \mathrm{Ca}^{-1}$, using age as covariate. ${ }^{*} \mathrm{p}<0.05,{ }^{* *} \mathrm{p}<0.01,{ }^{* * *} \mathrm{p}<0.001$

\begin{tabular}{|lcll|}
\hline a) & df & $\mathrm{Mg} \mathrm{Ca}^{-1}$ & $\mathrm{Mn} \mathrm{Ca}^{-1}$ \\
\hline Sampling area & 7 & 0.00426 & 7.881 \\
Residual & 316 & $0.00009^{* * *}$ & $0.379^{* * *}$ \\
b) & df & $\mathrm{Sr} \mathrm{Ca}^{-1}$ & $\mathrm{Ba} \mathrm{Ca}^{-1}$ \\
\hline Sampling area & 7 & 0.00032 & 0.0861 \\
Age & 1 & 0.00385 & 0.5894 \\
Residual & 315 & $0.00006^{* * *}$ & $0.0075^{* * *}$ \\
\hline
\end{tabular}

For $\mathrm{Mn} \mathrm{Ca}^{-1}$, residuals fulfilled parametric assumptions $\left(\mathrm{F}_{\max }, \alpha=0.05\right.$; Kolmogorov-Smirnov $\left.\mathrm{p}>0.05\right)$, except for evidence of some negative skewness at South Georgia alone. The hierarchical model showed significant differences at both levels (ANOVA: $\mathrm{p}<0.5$ ). The 1-way model showed significant differences (ANOVA: p < 0.05) (Table 2a), and SNK tests showed that mean values for the Patagonian Shelf areas and the western Scotia Ridge separated significantly from the eastern Scotia Ridge, Shag Rocks, and South Georgia, by up to 2.6 SD in the case of the southern FCZ and eastern Scotia Ridge. There were smaller, though significant, differences among areas in the Subantarctic Zone: north FCZ separated from the sample in international waters by $0.56 \mathrm{SD}$ and south FCZ by $0.91 \mathrm{SD}$. The eastern Scotia Ridge also separated from Shag Rocks and South Georgia, showing mean $\mathrm{Mn} \mathrm{Ca}^{-1}$ concentrations lower than all other areas.

For $\mathrm{Sr} \mathrm{Ca}^{-1}$, the full hierarchical model, with sex as the blocking factor and age as the covariate, showed significant differences between and within zones (ANCOVA: $p$ <.05). However, it also showed affinity be- 
tween the western Scotia Ridge and sampling areas in the Subantarctic Zone, and between the eastern Scotia Ridge and areas in the Antarctic Zone. Using the 1way blocked ANOVA, with sampling area as the treatment, sex as the blocking factor, and age as the covariate, we found significant differences (ANCOVA: p < 0.05) between the eastern Scotia Ridge, Shag Rocks and South Georgia on the one hand, and international waters, south FCZ and west Scotia Ridge on the other (by up to 1.10 SD); and there were no significant differences between international waters, south $\mathrm{FCZ}$, and the western Scotia Ridge, or between the eastern Scotia Ridge, Shag Rocks and South Georgia (Table 2b). Removing the block and adding north FCZ had little effect on these results (ANCOVA: $p<0.05$ ), with north FCZ showing differences only from the eastern Scotia Ridge, Shag Rocks, and South Georgia. Even with the age effect accounted for, the eastern FCZ showed a mean concentration between that for international waters, south FCZ, the west and east Scotia Ridge, Shag Rocks, and South Georgia: it was significantly different from both south FCZ and the eastern Scotia Ridge, at opposite ends of the range. $\mathrm{Ba} \mathrm{Ca}^{-1}$ gave a similar picture. Using the full 1-way model (Table 2b), we found significant differences (ANCOVA: $p<0.05$ ) between the eastern Scotia Ridge, Shag Rocks, and South Georgia on the one hand, and international waters, south FCZ and the west Scotia Ridge on the other. Removing the block had little effect on these results (ANCOVA: $\mathrm{p}<0.05$ ). Sampling areas differed by up to $1.53 \mathrm{SD}$. Again, the east FCZ had an intermediate mean value, and was significantly different from south FCZ and the eastern Scotia Ridge. However, it was also significantly different from north FCZ; the eastern Scotia Ridge, at the other end of the range, was significantly different from all other areas. International waters also differentiated from the north and south FCZ, though only marginally ( $p=0.049$ and 0.03 , respectively).

The multivariate analyses indicated that contrasts in age and element ratio distributions between sampling areas were strong enough to support accurate classification of provenance for many areas. MDS illustrated differences in the Subantarctic Zone between the north, east, and south FCZ with stress $=0.126$ in 2 dimensions (Fig 5a). East FCZ also separated from sampling areas in the Polar Frontal Zone, where the eastern clearly differentiated from the western Scotia Ridge (Fig. 5b), and in the Antarctic Zone, where Shag Rocks and South Georgia were distributed similarly (Fig. 5c). By incorporating age with the chemistry data, the quadratic MDA improved classification rates by $14 \%$ compared to chemistry data de-trended for age. It classified $74 \%$ of fish from the Patagonian Shelf correctly (Table 3), compared to prior probabilities of between 9 to $14 \%$ by random chance alone.
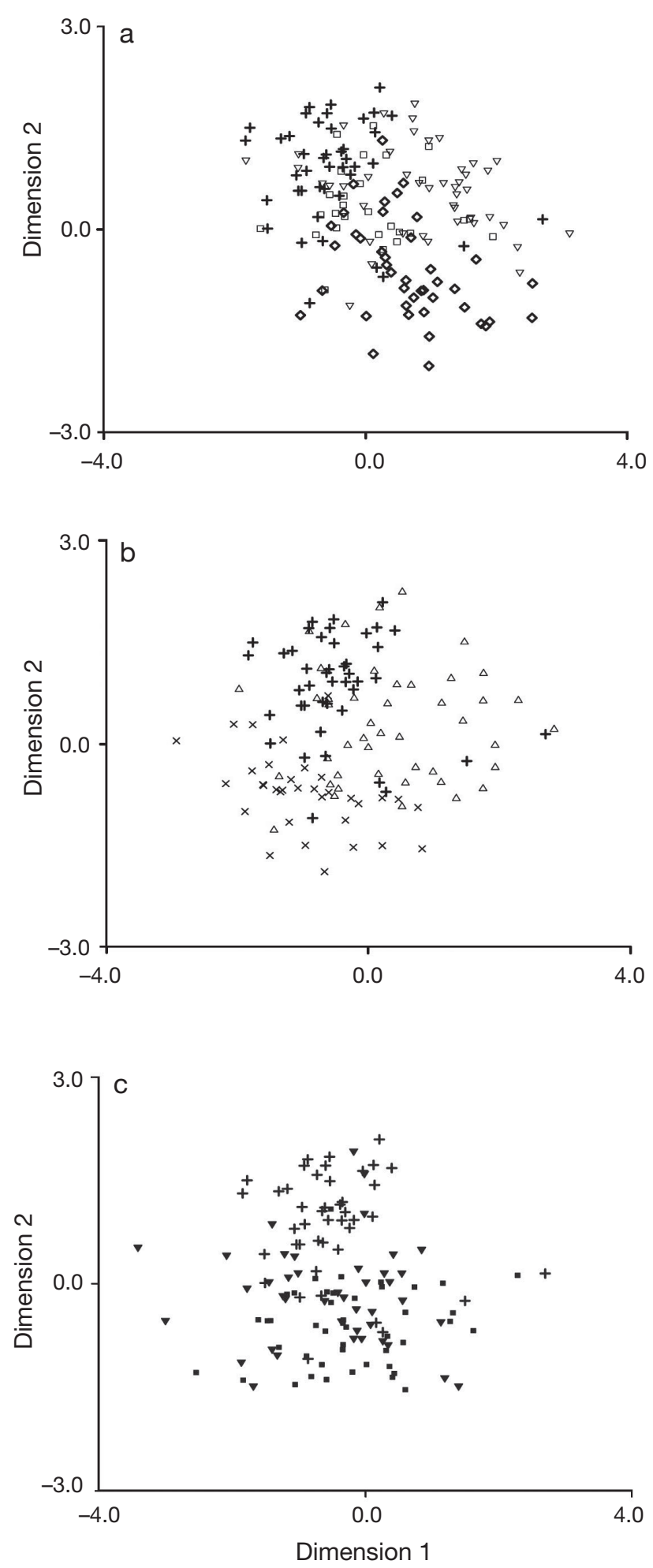

Fig. 5. Dissostichus eleginoides. Spatial relationships from otolith edge chemistry using non-metric multidimensional scaling (stress $=0.126$ for 2 dimensions). (a) International waters (ㅁ), north FCZ (॰), east FCZ (+), south FCZ ( $\nabla)$; (b) west $(\Delta)$ and east $(\times)$ North Scotia Ridge; (c) Shag Rocks ( $\square)$ and South Georgia ( $\mathbf{v})$. East FCZ is shown as reference 
Table 3. Dissostichus eleginoides. Classification rates (\%) from quadratic multivariate discriminant analysis, based on $\mathrm{Mg} \mathrm{Ca}^{-1}$, $\mathrm{Mn} \mathrm{Ca}^{-1}, \mathrm{Sr} \mathrm{Ca}^{-1}, \mathrm{Ba} \mathrm{Ca}^{-1}$ and age. Sampling areas are as defined in Fig. 3

\begin{tabular}{|c|c|c|c|c|c|c|c|c|}
\hline Classified to: & INT & $\mathrm{NFCZ}$ & EFCZ & SFCZ & WSR & ESR & SR & $\mathrm{SG}$ \\
\hline INT & 57 & 11 & 11 & 4 & 4 & 0 & 4 & 11 \\
\hline NFCZ & 5 & 83 & 2 & 0 & 2 & 2 & 2 & 2 \\
\hline EFCZ & 2 & 2 & 77 & 12 & 0 & 5 & 2 & 0 \\
\hline SFCZ & 7 & 0 & 9 & 73 & 4 & 0 & 2 & 4 \\
\hline WSR & 13 & 11 & 16 & 29 & 18 & 0 & 2 & 11 \\
\hline ESR & 3 & 6 & 0 & 0 & 3 & 71 & 9 & 9 \\
\hline SR & 4 & 9 & 2 & 2 & 9 & 18 & 40 & 16 \\
\hline SG & 7 & 10 & 7 & 2 & 2 & 7 & 10 & 55 \\
\hline Priors & 0.086 & 0.130 & 0.133 & 0.139 & 0.139 & 0.105 & 0.139 & 0.130 \\
\hline
\end{tabular}

Fish from the eastern Scotia Ridge classified $71 \%$ correctly, but classification success was lower for Shag Rocks (40\%) and South Georgia (55\%), and only slightly better than random chance for the western Scotia Ridge. However, misclassifications were not evenly distributed between sampling areas: 15 of the 27 (56\%) misclassified fish from Shag Rocks were allocated to neighbouring sampling areas off the eastern Scotia Ridge and South Georgia, and 31 out of 37 (84\%) of western Scotia Ridge fish were allocated to sampling areas on the Patagonian Shelf. Therefore, taking the western Scotia Ridge as belonging to the South American region and the eastern Scotia Ridge as an Antarctic sampling area, 85.5\% of fish were classified to the correct region; only $5.9 \%$ of South American fish classified incorrectly to Antarctic sampling areas.

\section{DISCUSSION}

\section{Otolith chemistry in the ACC}

Strong contrasts in the chemistry laid down in fish between the Subantarctic and Antarctic Zones implied that frontal processes structuring the physical environment also structured the ambient biogeochemistry which otoliths record. In the Polar Frontal Zone, sampling areas were close to the average position of fronts, and fish showed affinities with neighbouring zones. Even so, the mean for the Polar Frontal Zone, intermediate between the western and eastern Scotia Ridge, differentiated significantly from both the Subantarctic and Antarctic Zones, suggesting that all 3 zones show characteristic chemistry. Moreover, we found age distributions of fish varied spatially as well and improved classification success.

Affinities in otolith chemistry between areas can arise through movement at fine temporal scales that homogenize spatial differences. However, both genetics (Shaw et al. 2004) and nucleus chemistry (Ashford et al. 2006) showed little exchange between fish from the eastern Scotia Ridge and further east, despite the similarities in their edge chemistry. Instead, meanders in the SAF and PF (e.g. Sprintall 2003) may bring water from the Subantarctic and Antarctic Zones on to the North Scotia Ridge. However, where the fronts cross the ridge, their displacement is constrained by bathymetry. Alternatively, in the Scotia Sea, poleward meanders in the SAF generate warm-core eddies, and equator-ward meanders in the PF generate cold-core eddies. Frequent but largely confined to the Polar Frontal Zone, these eddies follow a northeastward track towards the North Scotia Ridge (Sprintall 2003) bringing water entrained from neighbouring zones.

These mesoscale features may lead to biases in estimates of provenance between zones by inflating rates of misclassification from affected areas. Within zones, movement on fine temporal scales or lack of environmental differentiation may lead to similar otolith chemistry, such as around Shag Rocks and South Georgia, also inflating rates of misclassification. Nevertheless, our results demonstrate that otolith chemistry reflects oceanographic structure rather than geographic distance: within zone, differences observed between the north and east FCZ likely reflected the distribution of AAIW, which occupies depths to $1000 \mathrm{~m}$, and CDW lower down the slope (Arhan et al. 2002).

As a consequence, otolith chemistry is well suited for addressing population questions linked to physical processes. However, the feasibility and design of such studies depends on how variation is structured spatially. Keys to understanding this are the data distributions for each marker, and in particular, the strong empirical relationships we found between their means and SDs. By estimating these, we were able to transform the data to give homogeneous variances and normality, allowing application of the powerful range of techniques available in ANOVA. Blocks and covariates accounted for confounding variation and so greatly improved the resolving power of the analysis. Standard deviations separating each sampling area reflect 
resolving power and provide a measure of the relative strength of contrasts.

Previous studies have demonstrated that otolith chemistry can classify the provenance of oceanic fish at scales that match movement between regions (Ashford et al. 2005) and estuarine-dependent fish at scales confined to a single estuary (Dorval et al. 2005). Our results demonstrate that contrasts measured in oceanic systems can be sufficient at finer scales as well. The 4 chemical markers discriminated between sampling areas by up to 2.6 SD, which, when combined with age, led to classification rates of 57 to $83 \%$ along the Patagonian Shelf. At this scale, age improved classification rates by $14 \%$ : South American-caught fish were identified to region with over $94 \%$ success, which compared well to previous classification rates of $95 \%$ between South America and the Antarctic (Ashford et al. 2005).

\section{Properties, gradients, and contrasts}

These contrasts were consistent with prior evidence of the properties of each otolith marker (Ashford et al. 2005). Reflecting activity near South America, $\mathrm{Mn} \mathrm{Ca}^{-1}$ discriminated fish caught off the Patagonian Shelf from those sampled off the eastern Scotia Ridge and in the Antarctic Zone. Sr $\mathrm{Ca}^{-1}$ distinguished them as well, consistent with exposure to ambient temperatures in $\mathrm{CDW}$ and $\mathrm{AAIW}$; and $\mathrm{Ba} \mathrm{Ca}^{-1}$ did the same, consistent with nutrient mixing along isopycnals and production fueled by nitrate. Results from east FCZ provided further support: near to South America yet exposed to CDW, Mn $\mathrm{Ca}^{-1}$ was similar to other South American areas, but $\mathrm{Sr} \mathrm{Ca}^{-1}$ and $\mathrm{Ba} \mathrm{Ca}^{-1}$ showed affinity to the eastern Scotia Ridge, Shag Rocks, and South Georgia.

$\mathrm{Mg} \mathrm{Ca}^{-1}$ concentrations, thought to be more related to physiological processes like activity and reproduction (Campana 1999, Bath Martin \& Thorrold 2005), nevertheless showed spatial variation as well. Concentrations were high at all 3 sampling areas closest to where the SAF crosses the North Scotia Ridge. Higher activity may be a response to local current jets or eddies. Alternatively, high mean $\mathrm{Mg} \mathrm{Ca}^{-1}$ may be linked to spawning on the Burdwood Bank, which occurred during 2 peaks in May and August (Laptikovsky et al. 2006); distributions of $\mathrm{Mg} \mathrm{Ca}^{-1}$ may therefore reflect the relative amount of time lapsed for dispersal of spent spawners associated with each peak.

The properties of these markers suggest the environmental gradients that otolith chemistry can resolve. Variability in temperature-salinity relationships (e.g. Arhan et al. 2002) decreases rapidly in deeper water, so temperature-driven deposition of otolith $\mathrm{Sr} \mathrm{Ca}^{-1}$ is likely to be robust as an indicator of
CDW exposure. Since temperature also differentiates upper and lower $\mathrm{CDW}, \mathrm{Sr} \mathrm{Ca}^{-1}$ represents a powerful tool to test for movement between water masses up and down the continental slope. Indeed, similarities to north FCZ in the otolith chemistry of several fish caught at east FCZ suggested that these fish had moved to depth during 2001. On the other hand, the properties of $\mathrm{Mn} \mathrm{Ca}^{-1}$ and $\mathrm{Ba} \mathrm{Ca}^{-1}$ make them useful to test for horizontal movement. $\mathrm{Mn} \mathrm{Ca}^{-1}$ and $\mathrm{Ba} \mathrm{Ca}^{-1}$ also discriminated at finer scales within the Subantarctic Zone and near the PF where Mn-depletion and Ba-enrichment along the eastern Scotia Ridge was consistent with transport from nitrate-fuelled regions in the Scotia Sea.

These markers are most useful where their properties contrast most: for example, in this study between $\mathrm{Mn} \mathrm{Ca}^{-1}$ and $\mathrm{Sr} \mathrm{Ca}{ }^{-1}$ at east $\mathrm{FCZ}$, or $\mathrm{Sr} \mathrm{Ca}^{-1}$ and $\mathrm{Ba}$ $\mathrm{Ca}^{-1}$ off the eastern Scotia Ridge. But even multiple markers may not resolve situations where none shows a strong environmental gradient. Before designing population studies, therefore, researchers need to consider the unique properties of each marker and where they generate the contrasts that can support application of otolith chemistry.

\section{Otolith chemistry and spatial ecology}

Our results strongly suggest that otolith chemistry records environmental structuring by frontal processes. But frontal processes in the ACC structure populations as well. Young krill lost to parent populations off the northern Antarctic Peninsula are transported to South Georgia where they form large non-breeding swarms (Hofmann et al. 1998). In Patagonian toothfish, advection by frontal currents appears to explain not only the population boundary delineated by the PF (e.g. Ashford et al. 2003, Rogers et al. 2006), but also evidence of movement and mixing along the ACC (Ashford et al. 2007).

However, while nucleus chemistry showed the population boundary at the $\mathrm{PF}$, it found no similar boundary across the SAF. From the North Scotia Ridge, water in the PF flows eastward across the Atlantic, so advection may lead to mortality or to connectivity downstream in the ACC. On the other hand, the SAF connects the North Scotia Ridge to the Patagonian Shelf (Arhan et al. 2002). Spent fish found east of the Falklands disperse from spawning areas on the Burdwood Bank (Laptikovsky et al. 2006), consistent with SAF transport. As a result, the 2 fronts structure population processes at different scales: advection in the PF may link areas in different ocean basins, but advected fish are effectively lost to the parent population. Advection in the SAF, on the other hand, may 
determine the size of the migration loop South American toothfish have to make in order to spawn, and with it, their survival and contribution to future recruitment.

Hydrography has been widely implicated in structuring the population processes of marine fish (e.g. Sinclair 1988, Sinclair \& Iles 1989). Our results strongly suggest that differences in otolith chemistry are often related to the same physical processes: for most otolith markers, it is between water masses and between zones separated by sharp oceanic trends like fronts that contrasts are most pronounced and provenance is most well-defined. The ensuing relationships between ocean structure, population processes, and the contrasts otolith chemistry can discriminate argue that the technique can link fish not only to their physical environment, but also to the spatial distribution of the vital rates that govern abundance and persistence and, hence, provide a uniquely powerful tool for examining their spatial ecology.

Acknowledgements. We thank the fishery observers at the Falkland Island Fisheries Department (Stanley, Falkland Islands) and the Marine Resources Assessment Group (London, UK), who collected the samples. We are also indebted to our colleagues at Old Dominion University: E.E. Hofmann, of the Center for Coastal Physical Oceanography, for many insights on physical-biological interactions; D.N. Naik, of the Mathematics and Statistics Dept., for advice on statistical methodology; Z. Chen, at LITER, for expertise in ICPMS techniques; and E. Larsen at CQFE, who prepared the otoliths and ran the ICPMS assays. J.R.A., A.I.A., C.M.J. were funded by the Falkland Islands Government. J.R.A. and C.M.J. were also funded by the National Science Foundation (NSF OPP0338294).

\section{LITERATURE CITED}

Agnew DJ, Heaps L, Jones C, Watson A, Berkieta K, Pearce J (1999) Depth distribution and spawning pattern of Dissostichus eleginoides at South Georgia. CCAMLR Sci 6:19-36

Appleyard SA, Ward RD, Williams R (2002) Population structure of the Patagonian toothfish around Heard, McDonald and Macquarie Islands. Antarct Sci 14:364-373

Arhan M, Naveira Garabato AC, Heywood KJ, Stevens DP (2002) The Antarctic Circumpolar Current between the Falkland Islands and South Georgia. J Phys Oceanogr 32: 1914-1931

Ashford JR (2001) In support of a rationally managed fishery: age and growth in Patagonian toothfish (Dissostichus eleginoides). PhD dissertation, Old Dominion University, Norfolk, VA

Ashford JR, Jones CM, Bobko S, Everson I (2002) Length-atage in juvenile Patagonian toothfish (Dissostichus eleginoides). CCAMLR Sci 9:1-10

Ashford JR, Jones CM, Hofmann E, Everson I, Duhamel G (2003) Is population structure of Patagonian toothfish (Dissostichus eleginoides) determined by the Antarctic Circumpolar Current? CCAMLR Sci Papers WG-FSA-03/84

Ashford JR, Jones CM, Hofmann EE, Everson I, Duhamel G, Moreno C, Williams R (2005) Can otolith elemental signatures record the capture site of Patagonian toothfish (Dis- sostichus eleginoides), a fully marine fish in the Southern Ocean? Can J Fish Aquat Sci 62:2832-2840

Ashford JR, Arkhipkin AI, Jones CM (2006) Can the chemistry of otolith nuclei determine population structure of Patagonian toothfish (Dissostichus eleginoides)? J Fish Biol 69:708-721

Ashford JR, Jones CM, Hofmann EE, Everson I, Duhamel G, Moreno C (2008) Otolith chemistry indicates population structuring by the Antarctic Circumpolar Current. Can J Fish Aquat Sci (in press)

Bath Martin G, Thorrold SR (2005) Temperature and salinity effects on magnesium, manganese and barium incorporation in otoliths of larval and early juvenile spot Leiostomus xanthurus. Mar Ecol Prog Ser 293:223-232

Bucciarelli E, Blain S, Treguer P (2001) Iron and manganese in the wake of the Kerguelen Islands (Southern Ocean). Mar Chem 73:21-36

Campana SE (1999) Chemistry and composition of fish otoliths: pathways, mechanisms, and applications. Mar Ecol Prog Ser 188:263-297

Dehairs F, Baeyens W, Goeyens L (1992) Accumulation of suspended barite at mesopelagic depths and export production in the Southern Ocean. Science 258 (5086): 1332-1335

Donat JR, Bruland KW (1995) Trace elements in the oceans. In: Salbu B, Steinnes E (eds) Trace elements in natural waters. CRC Press, Boca Raton, FL, p 247-281

Dorval E, Jones CM, Hannigan R, van Montfrans J (2005) Can otolith chemistry be used for identifying essential seagrass habitats for juvenile spotted seatrout, Cynoscion nebulosus, in Chesapeake Bay? Mar Freshwat Res 56: 645-653

Eastman JT (1993) Antarctic fish biology: evolution in a unique environment. Academic Press, San Diego, CA

Hofmann EE (1985) The large-scale structure of the Antarctic Circumpolar Current from FGGE drifters. J Geophys Res 90(C4):7087-7097

Hofmann EE, Klinck JM, Locarnini RA, Fach B, Murphy E (1998) Krill transport in the Scotia Sea and environs. Antarct Sci 10(4):406-415

Horn PL (2002) Age and growth of the Patagonian toothfish (Dissostichus eleginoides) and Antarctic toothfish (D. mawsoni) in waters from the New Zealand subantarctic to the Ross Sea, Antarctica. Fish Res 56(3):275-287

Khattree R, Naik DN (1999) Applied multivariate statistics with SAS ${ }^{\circledR}$ software, 2nd edn. SAS Institute and John Wiley \& Sons, New York

Khattree R, Naik DN (2000) Multivariate data reduction and discrimination with SAS ${ }^{\circledR}$ software. SAS Institute and John Wiley \& Sons, New York

Kruskal JB, Wish M (1978) Multidimensional scaling. Sage Publications, Beverly Hills, CA

Kuehl RO (1994) Statistical principles of research design and analysis. Duxbury Press, Belmont, CA

Laptikovsky V, Arkhipkin A, and Brickle P (2006) Distribution and reproduction of the Patagonian toothfish Dissostichus eleginoides Smitt around the Falkland Islands. J Fish Biol 68:849-861

Loeb VJ, Kellermann AK, Koubbi P, North AW, White MG (1993) Antarctic larval fish assemblages: a review. Bull Mar Sci 53(2):416-449

Meredith MP, Grose KE, McDonagh EL, Heywood KJ, Frew RD, Dennis PF (1999) Distribution of oxygen isotopes in the water masses of Drake Passage and the South Atlantic. J Geophys Res 104(C9):20949-20962

Moller PR, Nielsen JG, Fosse I (2003) Patagonian toothfish found off Greenland. Nature 421:599 
North AW (2002) Larval and juvenile distribution and growth of Patagonian toothfish around South Georgia. Antarct Sci 14(1):25-31

Nowlin WD Jr, and Clifford M (1982) The kinematic and thermohaline zonation of the Antarctic Circumpolar Current at Drake Passage. J Mar Res 40:481-507

Orsi AH, Whitworth T, Nowlin WD (1995) On the meridional extent and fronts of the Antarctic Circumpolar Current. Deep-Sea Res I 42(5):641-673

Pollard RT, Lucas JI, Read JF (2002) Physical controls on biogeochemical zonation in the Southern Ocean. Deep-Sea Res II 49:3289-3305

Rogers AD, Morley S, Fitzcharles E, Jarvis K, Belchier M (2006) Genetic structure of Patagonian toothfish (Dissostichus eleginoides) populations on the Patagonian Shelf and Atlantic and western Indian Ocean sectors of the Southern Ocean. Mar Biol 149(4):915-924

Editorial responsibility: Otto Kinne (Editor-in-Chief), Oldendorf/Luhe, Germany
Shaw PW, Arkhipkin AI, Al-Khairulla H (2004) Genetic structuring of Patagonian toothfish populations in the Southwest Atlantic Ocean: the effect of the Antarctic Polar Front and deep water troughs as barriers to genetic exchange. Mol Ecol 13(11):3293-3303

Sinclair M (1988) Marine populations: an essay on population regulation and speciation. University of Washington Press, Seattle

Sinclair M, Iles TD (1989) Population regulation and speciation in the oceans. J Cons Int Explor Mer 45:165-175

Smith P, McVeagh M (2000) Allozyme and microsatellite DNA markers of toothfish population structure in the Southern Ocean. J Fish Biol 57(Suppl A):72-83

Sprintall J (2003) Seasonal to interannual upper-ocean variability in the Drake Passage. J Mar Res 61:27-57

Thresher RE (1999) Elemental composition of otoliths as a stock delineator in fishes. Fish Res 43:165-204

Submitted: April 13, 2007; Accepted: July 12, 2007

Proofs received from author(s): November 15, 2007 